\title{
Perception and production of Mandarin lexical tones in Korean learners of Mandarin Chinese
}

\author{
Sungsil Ko · Jiyoun Choi* \\ Department of Social Psychology, Sookmyung Women's University, Seoul, Korea
}

\begin{abstract}
Non-tonal language speakers may have difficulty learning second language lexical tones. In the present study, we explored this issue with Korean-speaking learners of Mandarin Chinese (i.e., non-tonal first language speakers) by examining their perception and production of Mandarin lexical tones. In the perception experiment, the Korean learners were asked to listen to the tone of each stimulus and assign it to one of four Mandarin lexical tones using the response keys; in the production experiment, the learners provided speech production data for the lexical tones and then their productions were identified by native listeners of Mandarin Chinese. Our results showed that the Korean learners of Mandarin Chinese had difficulty in perceptually distinguishing Tone 2 and Tone 3, with the most frequent production error being the mispronunciation of Tone 3 as Tone 2. We also investigated whether unfamiliar non-native phonemes (i.e., Chinese phonemes) that do not exist in the native language phonemic inventory (i.e., Korean) may hinder the processing of the non-native lexical tones. We found no evidence for such effects, neither for the perception nor for the production of the tones.
\end{abstract}

Keywords: Mandarin Chinese, lexical tones, Korean learners of Chinese, perception, production

\section{1. 서론}

말소리는 분절음적 요소와 초분절음적 요소로 구성된다. 분 절음은 모음과 자음을 포함하며 어휘의 의미를 변별하는 기능 을 수행한다. 초분절음적 요소는 억양, 운율, 성조 등을 포함한 다. 표준 한국어(Seoul Korean)를 포함한 일부 언어에서 초분절 음은 어휘의 의미를 변별하는 기능을 수행하지는 않으며 음 위 에 얹혀서 강조나 정서 등을 표현해 주는 기능을 수행한다. 하 지만 다른 언어에서는 초분절음적 요소가 어휘의 의미를 변별
하는 기능을 수행하기도 한다.

초분절음적 요소인 성조가 어휘 의미의 변별 기능을 수행하 는 언어를 성조 언어라고 한다. 성조 언어에서의 성조는 음높이 (pitch)와 음조(contour)의 변화로 의미를 변별하는 기능을 수행 한다. 가령 성조 언어를 대표하는 언어 중 하나인 표준 중국어 (Mandarin Chinese)의 경우, 동일하게 $/ \mathrm{ma}$ 라는 음절로 발음되더 라도 음높이가 높고 평평하게 발음되는지(妈(mā)), 혹은 하강상승되는 조형으로 발음되는지(马(mă))에 따라 ‘엄마' 혹은 ‘말' 이라는 서로 다른 의미를 가지게 된다. 표준 중국어에는 4 개의

\footnotetext{
* jiyoun.choi@sookmyung.ac.kr, Corresponding author Received 29 January 2020; Revised 4 March 2020; Accepted 4 March 2020

(C) Copyright 2020 Korean Society of Speech Sciences. This is an Open-Access article distributed under the terms of the Creative Commons Attribution NonCommercial License (http://creativecommons.org/licenses/by-nc/4.0) which permits unrestricted non-commercial use, distribution, and reproduction in any medium, provided the original work is properly cited.
} 
성조가 있으며, 각 성조의 음높이를 오도제(5-level system: 1은 가장 낮은 음, 5 는 가장 높은 음을 표현)로 표현하면 다음과 같 다(Chao, 1968).

$$
\begin{aligned}
& \text { 1성: 음평(1성, ’), [55] } \\
& \text { 2성: 양평(2성, '), [35] } \\
& \text { 3성: 상성(3성, `), [214] } \\
& \text { 4성: 거성(4성, `), [51] }
\end{aligned}
$$

표준 중국어에는 자음의 역할을 하는 21 개의 성모와 모음의 역할을 하는 35 개의 운모(단운모, 복운모, 비운모, 권설운모, 결 합운모)가 있는 반면에 성조는 4개에 불과하다(Jin, 2015). 이와 같은 이유로 성모, 운모와 비교했을 때 4 개 성조 각각의 평균 출 현 빈도(평균 4음절에 한 번씩 출현)는 상당히 높다. 이 때문에 성조의 지각 혹은 산출이 정확하지 않은 경우 중국어를 통한 상 호작용에서 커다란 혼동이 발생할 수 있다. 따라서 중국어 성조 의 지각과 산출의 정확도는 중국어 사용에서 그 중요도가 높다 고 할 수 있다. 중국어와는 달리 표준 한국어는 비성조 언어로 음높이와 같은 초분절음적인 요소가 단어의 의미를 변별하는 기능을 수행하지 않는다. 이러한 한국어와 중국어의 차이로 인 하여 한국어 모국어 화자가 중국어를 학습할 때에 성조에서 어 려움을 보일 것으로 예측된다. 따라서 본 연구에서는 한국어 모 국어 화자가 표준 중국어를 외국어로 학습할 때에 성조의 지각 및 산출에서 어떤 어려움을 보이는지 알아보고자 한다.

선행 연구에 따르면, 한국어 모국어 화자들은 표준 중국어 4 개의 성조 중에서도 특히 2 성과 3 성에서 어려움을 보인다. 가령, Lee(2008)는 중국어를 배우기 시작한 지 6개월에서 1년 미만인 한국인 학습자들을 대상으로 중국어 성조 산출 실험을 진행하 였다. 음향분석 결과, 한국어 학습자는 중국어 모국어 화자에 비해 2성(오도제: [35], 상승조)의 기점과 종점의 음높이 차이가 좁았고, 3성(오도제: [214], 하강상승조)에서는 시작점의 음높이 가 낮은 특성을 보였다. $\operatorname{Sim}(1999)$ 은 중국어 학습 기간이 5년 이 상인 북경 소재 대학에 재학 중인 한국인 학생들을 대상으로 음 향 분석을 진행하였다. 연구 결과, 3 성 발화에서 음높이의 하강 이 잘 발화되지 못하여 2성과 유사한 상승조형을 보이는 오류 가 관찰되었다. 지각의 연구 결과 또한 산출 연구와 유사하였는 데, 가령 $\operatorname{Kim} \& \operatorname{Wang}(2015)$ 은 북경 소재 대학에서 수학 중인 평 균 중국어 학습 기간 $2 \sim 3$ 개월의 한국인 학생들을 대상으로 성 조 지각을 연구하였다. 그 결과, 지각에서도 2성과 3 성 간 혼동 이 보고되었다.

이러한 2성과 3 성 간 구분의 어려움이 지각과 산출 연구 모두 에서 유사하게 보고되고는 있지만, 위의 선행 연구들은 서로 상
이한 특징(가령, 상이한 중국어 학습 기간)을 가진 표본을 대상 으로 각개 연구가 진행되었다. 따라서 기존 연구만으로는 성조 학습에서 보이는 지각과 산출 간 유사성 및 상이성에 대한 이해 가 제한적일 수밖에 없다. 또한, Chen(1993)은 중국어 학습자가 보이는 성조에서의 오류 패턴이 지각과 산출에서 항상 일치하 는 것은 아닐 수 있다고 주장한다. 따라서 본 연구에서는 성조 학습에서 지각과 산출 간에 어떤 유사성 및 상이성이 있는지를 보다 깊게 이해하기 위하여, 비성조 언어인 한국어를 모국어로 하는 성인 중국어 학습자를 대상으로 중국어 성조의 지각과 산 출 연구를 함께 진행하고자 한다.

추가적으로 중국어 자음의 한국어와의 유사성이 중국어 성 조 지각 및 산출에 미치는 영향에 대해서도 탐구하고자 한다. 모국어에 없는 조음방법이나 조음위치로 발화되는 제 2 언어의 자음은 지각과 산출 모두에서 어려움을 보인다 $(\mathrm{Ko}, 2001$; Lee, 2018). 이러한 제 2 언어 자음의 지각 - 산출의 어려움은 성조의 지각 - 산출의 어려움을 가중시킬 수 있을 것으로 보인다. 이를 확인하기 위하여 본 연구에서는 한국어 자음과 유사한 중국어 자음, 그리고 한국어에서는 사용되지 않는 조음위치를 가진 중 국어 자음을 실험 자극으로 포함하여 연구를 진행하고자 한다 (유사성에 대한 자세한 설명은 아래 실험 자극 참고).

즉, 본 연구는 비성조 언어를 모국어로 하는 한국인 중국어 학습자를 대상으로 표준 중국어 성조의 지각 - 산출을 비교하 고자 한다. 이를 위해, (i) 성조의 지각 - 산출 정확도 및 반응시 간을 측정하여 한국어 모국어 화자가 중국어 학습 시에 어떤 성 조에서 주로 어려움을 보이는지, 또 이러한 어려움에서 지각과 산출 간 어떤 차이가 있는지를 알아보고자 한다. 또한, (ii) 오류 패턴 분석을 통해 지각 - 산출의 어려움이 구체적으로 어떤 성 조와의 혼동에서 비롯된 것인지를 확인하고자 한다. 마지막으 로, (iii) 중국어 자음의 한국어 자음과의 유사성을 조작하여 한 국어와 유사하지 않은 자음의 지각 - 산출 어려움이 성조의 어 려움을 가중시키는지 탐색하고자 한다.

\section{2. 방법}

\section{1. 실험 참가자}

한국어를 모국어로 하는 숙명여자대학교 중어중문학부 학부 생을 대상으로 실험을 진행하였다. 단, 중국어 이외의 성조 언 어 학습자 및 경상도 방언 구사자는 표집에서 제외하였다(Hao, 2012; Kim, 1991). 총 12명의 학부생이 소정의 참가 보상을 받고 자발적으로 실험에 참가하였다. 참가자의 평균 연령은 21.5 세 $(S D=1.51)$, 평균 중국어 학습 시작 연령은 16.83 세 $(S D=5.22)$, 평 균 중국어 학습 기간은 23.08 개월 $(S D=25.46)$ 이었다1. 모든 참가

\footnotetext{
1 학습 기간과 지각, 산출 정확도 간의 상관관계는 유의미하지 않았다[지각: $r(12)=.241, p=.450$; 산출: $r(12)=-271, p=.395]$. 선행 연구에 따르면, 중국어 입문 단계의 한국 인들에게서 나타났던 2성과 3성의 혼동이 초급 수준에 이르렀을 때 성조 언어 화자와 유사한 수준으로 2성과 3성을 지각할 수 있게 되었다고 한다(Kim \& Wang, 2015; 張林軍, 2010에서 재인용). 성조는 중국어 학습 초기 단계부터 그 학습이 이루어지고, 집중적인 학습을 하는 중국어 전공자들의 특성상 학습 기간에 따른 성조 정확도 상관이 유의미하지 않았을 것으로 보인다.
} 
자들은 듣고 말하는 데 어려움이 없었다.

\section{2. 실험 설계}

본 실험은 2(과제: 지각, 산출) $\times 4$ (성조: 1성, 2성, 3성, 4성)×2 (자음의 한국어 유사성: 유사함, 유사하지 않음) 참가자 내 설계 로 설계되었다. 측정 변인은 정확도(accuracy)와 반응 시간(RT, reaction time)이다.

\section{3. 실험 장치}

실험에 사용된 식별 과제(지각) 및 읽기 과제(산출)는 PsychoPy 3.2.4를 사용하여 제작되었다. 식별 과제에서는 LG Gram 14 "I5-6200U 노트북과 연결된 Shure 사의 SRH-440 헤드셋을 통해 자극을 제시하였고 키보드 숫자 버튼으로 반응을 입력받았다. 읽기 과제를 포함한 모든 녹음에는 Shure 사의 KSM- 44A/SL 마 이크와 TASCAM 사의 DR-680M 기종 디지털 레코더를 사용하 여 $16 \mathrm{bit}, 44,100 \mathrm{~Hz}$ 로 디지털화하였다.

\section{4. 실험 자극 및 절차}

실험은 조용한 실험실에서 개별적으로 진행되었다. 참가자 는 실험에 대한 충분한 설명을 들은 뒤 서면 동의서를 작성하였 다. 실험은 지각, 산출 순서로 진행되었다.

\subsection{1. 지각}

성조 지각 능력을 측정하기 위해 음성 자극을 듣고 해당 자극 이 어떤 성조로 들리는지 반응하는 식별 과제(identification task) 를 실시하였다.

총 6개의 $\mathrm{CV}$ (consonant-vowel) 단음절이 실험 자극으로 사용 되었다. 이 중 3 개 음절은 한국어와 유사한 자음으로 시작하고 (pa, nu, xi) 나머지 3개 음절은 유사하지 않은 자음을 포함하도 록(cha, zhu, shi) 구성하였다. 한국어 유사성의 기준은 Jeon (1999)의 분석을 참고하였는데, 한국어와 유사한 자음은 발음, 변이음, 기식의 길이가 한국어 자음과 근접한 자음을 포함하였 고 한국어와 유사하지 않은 자음은 한국어 음소에는 없는 조음 위치를 가진 설첨후음을 포함하였다. 이 6개의 CV 음절에 4개 표준 중국어 성조를 적용하여 총 24 개의 자극을 구성하였다.

한 명의 중국어 모국어 화자가 24 개의 실험 자극을 녹음하였 다. 이 화자는 중국 심양(潘陽) 출신의 성인 여성으로 북경에서 사용하는 표준 중국어를 구사하였다. 각 음절을 4회 반복하여 총 96개(26개 음절 $\times 4$ 회)의 음성 자극을 녹음하였다. 녹음 음성 의 정확도를 확인하기 위하여 2 명의 중국어 모국어 청자를 대 상으로 녹음 음성을 들려준 뒤 성조를 평가하도록 하였다. 그 결과 평균 $98.5 \%$ (각 $99 \%$ 와 $98 \%$ )의 정확도를 보였다.

본 실험에서, 실험 참가자는 노트북 앞에 앉아 실험 절차가 기술된 지시문을 읽었다. 지시문을 이해하였는지 확인한 후, 4 회의 연습 시행을 실시하였으며, 연습 시행이 끝난 직후 본 시 행을 진행하였다. 본 시행은 96회로 휴식 없이 진행하였으며 자 극은 무작위 순으로 제시되었다. 각 시행에서 $600 \mathrm{~ms}$ 동안 빈 화 면이 제시된 후 음성 자극이 헤드셋을 통해 제시되었다. 음성
자극 제시와 동시에 4개의 성조 선택지(성조 숫자 및 그래픽으 로 구성)가 화면에 제시되었다. 참가자는 제시된 음성 자극이 4 개의 성조 중 어떤 성조에 해당하는지 키보드 숫자 버튼을 눌러 반응하였다. 반응 시간에 제한은 없었으며, 반응 직후 빈 화면 이 제시되면서 다음 시행이 진행되었다.

식별 과제를 통해 지각 정확도, 반응 시간, 오류 패턴의 오류 율을 측정하였다. 의도한 성조로 반응한 것을 정반응, 의도하지 않은 성조로 반응한 것을 오반응으로 하여 전체 반응 대비 정반 응 백분위로 정확도를 계산하였다. 그리고 청각 자극 제시 시점 부터 참가자 반응까지의 시간을 반응 시간으로 측정하였다. 오 류율은 성조별로 계산하였다. 예를 들어, '1성-2성' 오류 패턴의 오류율은 1 성 전체 응답 대비 1성을 2성으로 반응한 패턴 수를 백분위로 계산하였다. 이와 같이 측정한 정확도, 반응 시간, 오류 패턴의 오류율은 변인별로 평균 계산하여 분석에 사용하였다.

\subsection{2. 산출}

성조 산출 능력을 측정하기 위해 화면에 제시된 한어병음 (pinyin)을 소리내어 읽는 읽기 과제(read-aloud task)를 실시하였다.

지각 과제와 동일한 24 개의 실험 자극이 사용되었으며(6개 음절 $\times 4$ 개 성조), 4 회의 연습 시행 직후 본 시행을 실시하였다. 본 시행은 24 개의 자극을 2 회 반복하여 48 회 휴식 없이 진행하 였다. 각 시행에서, $600 \mathrm{~ms}$ 동안 빈 화면이 제시된 후 회색 바탕 화면에 성조 표기가 된 한어병음이 제시되었다. 참가자는 제시 된 한어병음을 소리 내어 읽도록 지시받았고 과제 진행 동안 참 가자들의 발화는 녹음되었다. 키보드의 spacebar를 누르면 빈 화면이 제시되면서 다음 시행이 진행되도록 하였다.

읽기 과제를 통해 녹음된 참가자들의 음성을 2 명의 중국어 모국어 청자에게 제시한 후 어떤 성조로 들리는지 평정하도록 하였다. 평정에는 지각 과제로 사용된 동일한 식별 과제가 사용 되었다. 4회의 연습 시행 후, 총 576회의 시행이 진행되었다(6개 음절 $\times 4$ 개 성조 $\times 2$ 회 반복 $\times 12$ 명의 참가자). 자극은 무작위 순으 로 제시되었으며, 평정자의 피로를 최소화하기 위해 200회 시 행을 진행한 후 5 분간 휴식 시간을 두어 3 번에 걸쳐 진행되었다. 2 명의 평정자는 $92.32 \%$ 의 높은 일치도를 보였다 $(\mathrm{K}=.889$, $p<.001)$.

분석에서는 2 명의 평정자의 응답을 통합하였다(즉, 참가자 별 48개 산출은 총 96 개의 데이터를 갖게 됨). 참가자의 산출에 대한 평정자 식별을 통해 정확도, 반응시간, 오류 패턴의 오류 율의 세 가지 변인을 측정하였다. 측정 방식은 지각 과제와 동 일하였다.

\section{3. 결과 분석}

지각과제와 산출과제에서 측정한 참가자들의 각 조건별 평 균 정확도와 평균 반응시간을 분석에 사용하였다. 단, 반응 시 간이 10 초 이상인 4 개 시행( 3 개 산출 과제, 1 개 지각 과제)은 분 석에서 제외하였다. 


\section{1. 정확도(Accuracy)}

중국어 자음의 한국어와의 유사성 여부 및 성조에 따른 지각 과 산출의 정확도를 알아보기 위하여 성조(4 수준: 1 성, 2 성, 3 성, 4 성), 한국어 유사성(2 수준: 유사함, 유사하지 않음), 과제(2 수준: 지각, 산출)를 독립변인으로 하는 반복측정 분산 분석 (repeated measures ANOVA)을 실시하였다. 참가자 분석(F1)과 항목 분석 $(F 2)$ 을 함께 실시하였다.

분석 결과, 성조의 주효과가 유의미하였다 $[F 1(1.518,16.694)=$ 29.48, $p<.001 ; F 2(3,16)=63.58, p<.001]$. Least Significant Difference (LSD) 사후 분석 결과, 3 성(64\%)이 나머지 1 성 $(96 \%)$, 2성 $(88 \%)$, 4 성 $(97 \%)$ 에 비해 유의미하게 낮은 정확도를 보였고( $p s<.01), 2$ 성이 1성과 4성에 비해 유의미하게 낮은 정확도를 보였으며 $(p s<.01), 1$ 성과 4성 간 차이는 유의미하지 않았다. 과제 주효과 역시 항목 분석에서 유의미하게 나타났는데(참가자 분석에서는 경향성을 보임) $[F 1(1,11)=3.40, p=.09 ; F 2(1,16)=7.00, p<.05]$, 이는 지각과제 $(88 \%)$ 의 정확도가 산출과제 $(85 \%)$ 의 정확도에 비 해 유의미하게 높았음을 보여준다. 반면 한국어 유사성의 주효 과는 유의미하지 않았다.

과제 $\times$ 성조 상호작용 효과가 유의미하였다 $[F 1(1.315,14.463)=$ $12.39, p<.01 ; F 2(3,16)=51.72, p<.001] .1$ 성과 2 성에서는 산출과 제의 정확도가 지각과제의 정확도보다 유의미하게 높았으나 [1 성: $t(11)=-2.36, p<.05 ; 2$ 성: $t(11)=-2.30, p<.05], 3$ 성에서는 지각 과제의 정확도가 산출과제에 비해 유의미하게 높았다 $[t(11)=$ $3.86, p<.01]$ (그림 1). 그 외 상호작용은 모두 유의미하지 않았다.

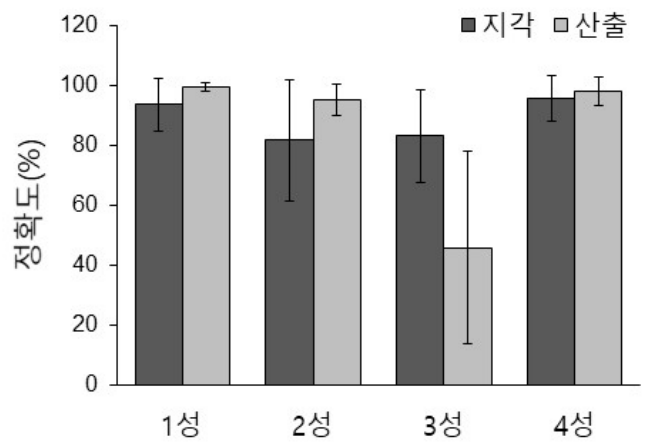

그림 1. 과제와 성조별 평균 정확도

Figure 1. The mean accuracy rates for each tone in perception and production tasks

\section{2. 반응시간(Reaction time)}

정확도 분석과 마찬가지로 성조(4 수준: 1 성, 2 성, 3 성, 4 성), 한국어 유사성(2 수준: 유사함, 유사하지 않음), 과제(2 수준: 지 각, 산출)를 독립변인으로 하는 참가자 분석( $F 1)$ 과 항목 분석 $(F 2)$ 을 실시하였다.

반응시간의 결과는 전반적으로 정확도와 유사한 패턴을 보
였다. 우선, 성조의 주효과가 유의미하였다 $[F 1(1.527,16.799)=$ $38.13, p<.001 ; F 2(3,16)=27.87, p<.001] . \mathrm{LSD}$ 사후 분석 결과, 3 성(2.16s)이 나머지 1성(1.51s), 2성(1.79s), 4성(1.48s)보다 반응 시간이 유의미하게 느렸고 $(p s<.01), 2$ 성이 1 성과 4 성에 비해 유 의미하게 느렸으며 $(p s<.05], 1$ 성과 4 성 간 차이는 유의미하지 않 았다. 과제의 주효과는 참가자 분석에서는 유의미하지 않았으 나 항목 분석에서는 그 차이가 유의미하였다 $[F 1(1,11)=.91$, $p=.360, \mathrm{~F} 2(1,16)=7.53, p<.05]$. 이는 산출 과제 $(1.79 \mathrm{~s})$ 에 비해 지 각 과제 $(1.68 \mathrm{~s})$ 에서 반응 시간이 유의미하게 뺄랐음을 의미한 다. 반면, 한국어 유사성의 주효과는 유의미하지 않았다.

과제 $\times$ 성조 상호작용 효과 역시 유의미하였다 $[F 1(1.368,15.049)=$ $4.15, p<.05 ; F 2(3,16)=8.20, p<.01]$. 각 성조에 따른 과제 비교가 유의미하지는 않았으나 경향성을 살펴보면, 3 성에서는 지각 $(1.94 \mathrm{~s})$ 보다 산출(2.37s)에서 반응 시간이 더 느린 반면 다른 성 조들은 두 과제 간 반응시간이 유사하였다(그림 2). 그 외 상호 작용은 모두 유의미하지 않았다.

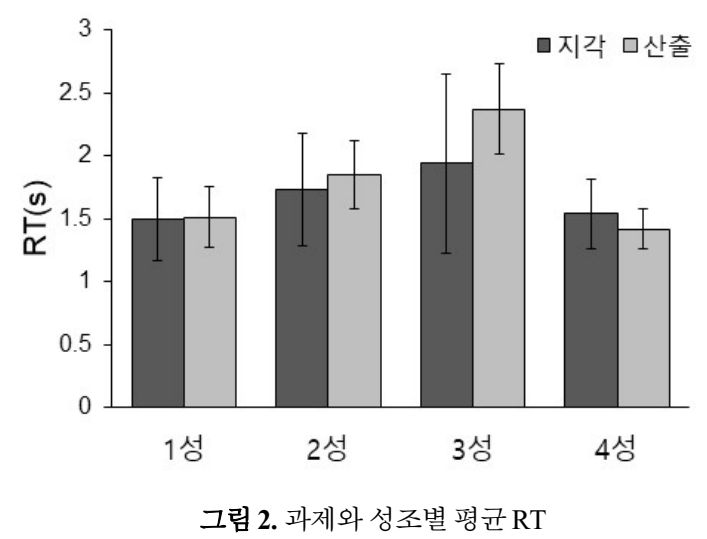

Figure 2. The mean RT for each tone in perception and production tasks

\section{3. 오류 패턴}

지각 및 산출에서 오류가 많이 발생하는 성조 패턴(가령, 2 성 을 3 성으로 잘못 지각하거나 발화; 이 경우 본 논문에서는 '2성 -3 성'으로 표현)을 알아보기 위하여 총 12 종류의 성조 오류 패 턴별로 오류율을 계산하였다(그림 3). 통계적 유의미성을 검증 하기 위하여 과제(2 수준: 지각, 산출)와 오류 패턴(12 수준: 1 성 -2성, 1성-3성, 1성-4성, 2성-1성, 2성-3성, 2성-4성, 3성-1성, 3성 -2성, 3성-4성, 4성-1성, 4성-2성, 4성-3성)을 독립변수로 하고 오 류율을 종속변수로 하는 반복 측정 분산 분석(참가자 분석)을 실시하였다. ${ }^{2}$

그 결과, 오류 패턴의 주효과가 통계적으로 유의미하였다 $[F(11,121)=33.26, p<.001] . \mathrm{LSD}$ 사후 분석 결과, 2성을 3 성으로 반응하는 오류 패턴(2성-3성: 11\%)과 3성을 2성으로 반응하는 오류 패턴(3성-2성: 34\%)이 다른 오류 패턴(모두 3\% 미만)보다 
유의미하게 높은 오류율을 보였고( $p s<.01), 3$ 성을 2성으로 반응 하는 오류 패턴(3성-2성)은 2성을 3성으로 반응하는 오류 패턴 (2성-3성)보다 유의미하게 높은 오류율을 보였다 $(p<.01)$ (그림 3). 과제의 주효과는 유의미하지 않았다.

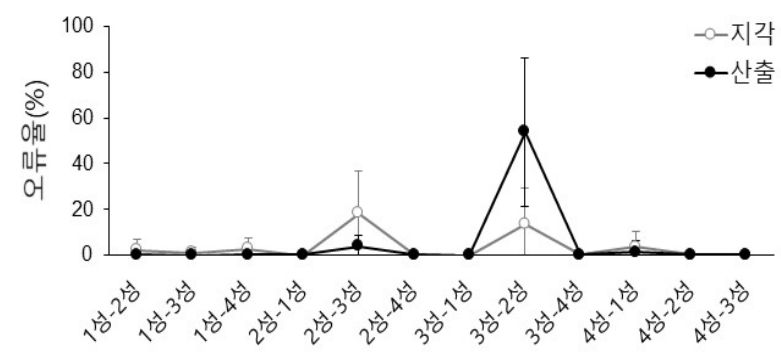

그림 3. 과제별 오류 패턴에 따른 오류율

Figure 3. The mean error rates for each error pattern in perception and production tasks

과제 $\times$ 오류 패턴의 상호작용이 유의미하였다 $[F(11,121)=$ $12.73, p<.001]$. 이는 2성을 3성으로 반응하는 오류 패턴(2성-3 성)에서는 산출(4\%)에 비해 지각(18\%)에서 오류율이 유의미하 게 높은 반면 $[t(11)=2.69, p<.05], 3$ 성을 2성으로 반응하는 오류 패턴(3성-2성)에서는 지각(14\%)에 비해 산출(54\%)에서 오류율 이 유의미하게 높았음을 보여준다 $[t(11)=-3.86, p<.01]$.

\section{4. 논의 및 결론}

본 연구에서는 비성조 언어를 모국어로 하는 한국인 중국어 학습자를 대상으로 표준 중국어 성조의 지각 - 산출의 정확도, 반응시간, 오류 패턴을 비교하였다. 본 연구의 주요 결과는 다 음과 같이 요약할 수 있다. 첫째, 1 성과 2성에서는 산출에 비해 지각에서 어려움을 보인 반면, 3성에서는 지각에 비해 산출에 서 더 큰 어려움을 보였다. 둘째, 2성-3성, 3성-2성 오류 패턴이 나머지 다른 오류 패턴에 비해 높은 오류율을 보였다. 오류 패 턴 별 지각-산출 비교에서 2성-3성 오류 패턴에서는 지각이 산 출보다 높은 오류율을 보인 반면, 3성-2성 오류 패턴에서는 산 출이 지각보다 높은 오류율을 보였다. 셋째, 중국어 자음의 한 국어 유사성 조작은 성조의 지각 - 산출 정확도, 반응시간, 오류 율에 영향을 주지 않았다.

우선, 본 연구에서는 각 성조별로 지각과 산출 간 차이가 있 음을 발견하였다. 이는 영어를 모국어로 하는 중국어 학습자를 대상으로 한 연구 결과와 유사하였다(Elliot, 1991). 구체적으로, Elliot(1991)에서는 본 연구와 동일한 과제로 지각과 산출을 연 구하였는데 그 결과 3성에서는 산출이 지각에 비해 높은 오류 율을 보인 반면에 나머지 $1,2,4$ 성에서는 지각이 산출에 비해 높은 오류율을 보였다. 이는 각 성조의 지각과 산출이 반드시 일대일 대응은 아니어서, 정확한 성조 지각이 정확한 산출로 꼭 이어지는 것이 아니며 또한 정확한 산출이 정확한 지각을 꼭 동 반하는 것도 아니라는 것을 보여 준다(Chen, 1993).

오류 패턴 분석에서는 전반적으로 2성-3성 패턴과 3성-2성
패턴이 다른 나머지 패턴에 비해 높은 오류율을 보였다. 하지만 오류 패턴에서도 지각과 산출 간 차이가 발견되었다. 즉, 지각 에서는 2성-3성 패턴과 3성-2성 패턴의 오류가 유사한 수준을 보였지만(그림 3 참고), 산출에서는 2성-3성 패턴에 비해 3성-2 성 패턴의 오류율이 높아서 2성-3성 패턴의 산출 오류율은 지각 오류율에 비해 유의미하게 낮고 3성-2성 패턴의 산출 오류율은 지각 오류율에 비해 유의미하게 높은 결과를 보였다. 이는 독일 어를 모국어로 하는 중국어 학습자를 대상으로 한 성조의 지각 과 산출 연구의 결과와 유사하다(Ding et al., 2011). 즉, Ding et al.(2011) 연구에서도 본 연구와 마찬가지로 지각에서는 2성과 3 성을 서로 혼동하였으나 산출에서는 3성을 2성으로 혼동하는 오류가 2성을 3성으로 혼동하는 오류에 비해 높았다.

이처럼 비성조 언어를 모국어(가령, 한국어와 독일어)로 하 는 중국어 학습자가 전반적으로 3 성을 2성으로 산출하는 경향 을 보이는 이유는 무엇일까? 3성은 급격한 음높이의 변화를 보 이는 성조로써 음높이 변화의 범위뿐만 아니라 하강-상승 변곡 점의 위치 및 음조의 기울기 등을 특징으로 갖는다. 하지만 비 성조 언어에서는 한 음절 안에서 급격한 음높이의 변화가 나타 나는 경우가 드물고 이에 따라 비성조 언어를 모국어로 하는 중 국어 학습자들은 음높이 변화의 범위(즉, 음높이의 최고점과 최저 점)에만 주의를 기울이는 것으로 보인다(Bradley, 2012; Gandour, 1983; Moore \& Jongman, 1997). 즉, 3성을 2성과 구분 지어주는 주요한 특징인 하강-상승 변곡점을 제대로 사용하지 못하여 3 성을 2성으로 발화하는 오류가 자주 발생한 것으로 보인다. 이 처럼 하나의 성조를 다른 성조와 구별 지어주는 요소를 생략하 여 발생하는 산출의 오류는 중국어 이외의 성조 언어인 베트남 어에서도 관찰되었다. Đào \& Nguyễn(2019)은 한국어를 모국어 로 하는 베트남어 학습자를 대상으로 베트남어 성조 산출을 연 구하였다. 그 결과 베트남어의 6성을 5성으로 산출하는 오류가 5 성을 6성으로 산출하는 오류에 비해 높았다. 베트남어의 5성 과 6성은 동일한 음높이 변화(하강-상승)를 보이지만 6성은 5성 과는 다르게 하강에서 자음의 후두화(laryngealization)를 동반한 다. 이는 6성 발화에서 자음의 후두화가 빈번하게 생략되거나 충분하지 못하여서 5 성으로 자주 혼동되기는 쉽지만, 그 역으 로 5성이 6성으로 혼동되는 경우는 흔치 않을 수 있음을 설명해 준다.

마지막으로 본 연구에서는 중국어 자음의 한국어와의 유사 성 조작이 성조의 지각과 산출에 영향을 주지 않았다. 즉, 한국 어와 유사한 자음을 초성으로 가진 음절의 성조에 비해 한국어 와 상이한 자음을 초성으로 가진 음절의 성조를 지각하거나 산 출하는 것이 더 어렵다는 결과를 찾지 못하였다. 이는 분절음 (본 연구에서는 자음)의 처리가 초분절음(본 연구에서는 성조) 처리에 영향을 미치지 않을 수 있다는 것을 시사한다. 하지만 본 연구에서 유사성의 조작이 제대로 가해지지 않았을 가능성 을 간과해서는 안 된다. 가령, 한국어 모국어 화자를 대상으로 실시한 중국어 어두 자음(initial consonants)의 지각 연구에서, 중국어의 설첨후음 $/ \mathrm{sh} /, / \mathrm{ch} /, / \mathrm{zh} /$ 는 각각 한국어의 /스 쓰/, /츠/, / 즈 쯔/로 범주화되는 경향을 보여 주었다(Lee, 2018). 이는 본 
연구에서 사용한 중국어의 설첨후음이 한국어에 없는 조음 위 치로 만들어지긴 하지만 한국어에서 사용되는 자음으로 쉽게 동화될 수 있음을 보여준다. 또한, 본 연구에서 사용된 실험 과 제 및 절차가 자음의 한국어 유사성 효과를 확인하기에 적합하 지 않았을 수도 있다. 가령, 실험 지시문에서는 본 연구가 성조 의 지각과 산출에 대한 것이라고 언급되어 있었고, 지각 과제에 서는 자극이 어떤 성조로 들리는지 직접적으로 응답해야 하는 식별 과제를 사용하였다. 이를 통해 참가자들이 실험의 관심 변 인이 성조라는 것을 쉽게 알아차렸을 것이며 이 때문에 참가자 들이 과제를 수행함에 있어서 자음에 주의를 주지 않아서 자음 의 효과가 나타나지 않았을 수 있다. 후속 연구에서 자음과 성 조에 모두 주의를 줘야하는 전사 과제(transcription) 등을 사용 하거나, 커버스토리와 디브리핑을 통해 참가자가 실험 관심 변 인을 모르도록 한다면 자음이 성조에 미치는 영향을 확인할 수 있을 것으로 보인다.

본 연구에서는 비성조 언어를 모국어로 하는 화자가 성조 언 어를 학습할 때 어려움을 보이는 성조에서 지각과 산출의 차이 가 있다는 것을 보여주었다. 이러한 연구 결과는 성조 학습에 대한 깊이 있는 이해를 위해서는 산출과 지각을 함께 연구할 필 요가 있음을 시사해준다.

\section{References}

Bradley, E. D. (2012). Tone language experience enhances sensitivity to melodic contour. LSA Annual Meeting Extended Abstract (Vol. 3, Article \#40). Portland, OR.

Chao, Y. R. (1968). A grammar of spoken chinese. Berkeley, CA: University of California Press.

Chen, Q. (1993). Toward a sequential approach for tonal error analysis. Proceedings of the Desert Language and Linguistic Society Symposium (Vol. 19, pp. 68-77). Provo, UT.

Ding, H., Hoffmann, R., \& Jokisch, O. (2011). An investigation of Tone perception and production in German learners of Mandarin. Archives of Acoustics, 36(3), 509-518.

Đào, Đ. M., \& Nguyễn, A. T. T. (2019). Korean L2 learners' perception and production of Vietnamese tones. Journal of Second Language Pronunciation, 5(2), 195-222.

Elliott, C. E. (1991). The relationship between the perception and production of Mandarin tones: An exploratory study. University of Hawai'i Working Papers in English as a Second Language, 10(2), 177-204.

Gandour, J. (1983). Tone perception in far Eastern languages. Journal of Phonetics, 11(2), 149-175.

Hao, Y. C. (2012). Second language acquisition of Mandarin Chinese tones by tonal and non-tonal language speakers. Journal of Phonetics, 40(2), 269-279.

Jeon, K. (1999). Phonetical analysis on Sino-Korean notating system for initial consonants. Korea Journal of Chinese Language and
Literature, 19(1), 347-375.

Jin, J. (2015). A study on Chinese pronunciation effective teaching methods for Koreean learners. The Review of Korean Cultural Studies, 52(2), 49-93.

Kim, H. R., \& Wang, J. Q. (2015). The study of perception of tone 2 and tone 3 in Chinese by Korean learner (elementary Chinese proficiency): Focused on the influence of the initial point, middle point, and final point of pitch frequency. Language \& Information Society, 26, 165-193.

Kim, J. (1991). Remarks on the high tone in Kyongsangdo dialect: With special reference to the middle Korean tone. Journal of The Linguistic Society of Korea, 13, 75-93.

Ko, M. (2001). A study on the relationship between segmental and suprasegmental phoneme in Korean and Chinese. Journal of Chinese Linguistics in Korea, 12, 235-256.

Lee, M. (2008). Tonal variation of Chinese Bisyllabic word for Korean speakers. Chinese Language \& Literature, 43, 613-634.

Lee, S. H. (2018). A study on the Korean's perception of Chinese initial consonant: Related with consonants categorization. The Journal of Chinese Cultural Studies, 42, 55-74.

Moore, C. B., \& Jongman, A. (1997). Speaker normalization in the perception of Mandarin Chinese tones. The Journal of the Acoustical Society of America, 102(3), 1864-1877.

Sim, S. H. (1999). A study on tone in a Chinese read by Koreans. The Journal of Chinese Language \& Literature, 6(1), 237-253.

\section{• 고성실 (Sungsil Ko)}

숙명여자대학교 사회심리학과 석사과정

서울시 용산구 청파로 100

Tel: 02-2077-7667

Email: kss0299@sookmyung.ac.kr

관심분야: 언어심리학, 음성학

- 최지연 (Jiyoun Choi) 교신저자

숙명여자대학교 사회심리학과 조교수

서울시 용산구 청파로 100

Tel: 02-2077-7331

Email: jiyoun.choi@sookmyung.ac.kr 관심분야: 언어심리학, 음성학 


\title{
중국어를 학습하는 한국어 모국어 화자의 중국어 성조 지각과 산출
}

\author{
고 성 실·최 지 연
}

숙명여자대학교 사회심리학과

\section{국문초록}

비성조 모국어 화자가 성조 언어를 학습할 때 모국어에 없는 성조 체계 학습에 어려움을 보인다. 본 연구는 비성조 언어인 한국어 모국어 성인 화자가 중국어를 학습할 때 중국어 성조의 지각과 산출에서 어떤 어려움을 보이는지 규명하고자 하였다. 추가적으로 중국어 분절음이 한국어와 유사하지 않을 경우 초분절음인 성조 지각 및 산출에 어려움을 가중시키는지 알아보기 위해 중국어 자음의 한국어 자음과의 유사성을 조작하여 실험을 진행하였다. 실 험 결과, 지각과 산출 간 정확도 및 반응시간이 각 성조 별로 차이를 보였다. 즉, 1 성과 2 성에서는 지각 과제에서 산 출 과제에 비해 어려움을 보인 반면 3성에서는 산출 과제에서 지각 과제보다 어려움을 보였다. 오류 패턴 분석 결 과, 지각 과제에서 2 성과 3 성을 서로 혼동을 하는 반면 산출 과제에서는 2 성을 3 성으로 산출하는 오류는 줄어들고 3 성을 2 성으로 산출하는 오류가 증가한 것을 보였다. 마지막으로, 한국어 유사성의 조작은 성조의 지각 및 산출에 영향을 주지 않았다.

핵심어: 성조 언어, 비성조 언어, 중국어 성조, 지각, 산출

\section{참고문헌}

고미숙 (2001). 한 · 중 분절음소와 초분절음소와의 관계 연구. 중 국언어연구, 12, 235-256.

김주원 (1991). 경상도방언의 고조의 본질과 중세 국어 성조와의 대응에 대하여. 언어학, $13,75-93$.

김해령, 왕건근 (2015). 한국어 초급 중국어 학습자의 중국어 성 조양평과 상성 지각 오류 연구: 기점, 전환점, 종점 변화의 영 향을 중심으로. 언어와 정보사회, 26, 165-193.

심소희 (1999). 한국인이 발음하는 중국어 성조의 문제와 개선. 중국어문학지, 6(1), 237-253.

이미경 (2008). 중국어 1·2 음절어 음높이 변화에 대한 한중 대조. 중어중문학, 43, 613-634.

이선희 (2018). 한국인의 중국어 어두자음 범주지각 연구. 중국문 화연구, 42, 55-74.

전광진 (1999). 중국어 자음의 한글 표기법에 대한 음성학적 대비 분석. 중국문학연구, 19(1), 347-375.

진준화 (2015). 한국인 학습자를 위한 효과적인 중국어 발음 교육 방안: 중국어 성조, 단운모 그리고 성모의 교육 방안 소개를 중 심으로. 한민족문화연구, 52(2), 49-93. 